\title{
Benefits of Innovative (ICT) Facilities Deployment on Construction Projects Delivery in Nigeria
}

Eze Emmanuel Chidiebere*1, Onyejeakor Hafex Ikemefuna ${ }^{2}$, Awodele Imoleayo Abraham $^{3}$ and Oladapo Kazeem Olalekan ${ }^{4}$

${ }^{1,3}$ Department of Quantity Surveying, Federal University of Technology, Owerri, Nigeria.

${ }^{2}$ Civil Engineering Department, River State University, Port Harcourt, Nigeria. ${ }^{4}$ Quantity Surveying Department, Federal University of Technology, Minna, Nigeria. *Correspondence author: emmanuel.eze@ futo.edu.ng

\begin{abstract}
Construction projects are data and information-laden, and there is the need to adopt and implement innovative ICT facilities in managing the volume of data and information generated; which hitherto are poorly handled. This is vital to exploit the opportunities presented by the strength that evolve from ICT adoption in corporate businesses. This study aims to assess the benefits of innovative ICT facilities adoption in construction project delivery in Nigeria. The study employed quantitative data gathered through wellstructured self-administered questionnaires to solicit information from construction professionals in the study area. With 68.28 percent response rate, frequencies, percentages, mean item score and Kruskal Wallis test were employed to analyze the gathered data. The most important benefits of ICT deployment in construction are increased productivity of employees, reduces mistakes/errors in contract documents, time-saving, enhanced marketability and competitiveness and ease of doing complex tasks. Also, no significant difference in the perception of construction professionals regarding the benefits of innovative ICT deployment in construction was observed. Construction organizations would need to embrace the benefits of ICT by adopting innovative facilities to boost performance and increase visibility and market share. Adequate plans and budget should be provided to reap the strategical, tactical and operational benefits of adopting innovative ICT solutions in construction project delivery.
\end{abstract}

Keywords: Construction Industry, construction professionals, Innovative facilities, ICT deployment, project delivery, Nigeria

\section{Introduction}

The construction industry is the prime mover and the mainstay of nations. The industry is adjudged as an influential sector that provides job and stimulates growth in the economy (Onyeagam et al., 2019). Thus, it is known as a great influencer and accelerator of national growth and development (Eze et al., 2019). However, the construction industry has been criticized for their poor productivity, efficiency and quality performance of product delivery (Sekuo, 2012). Similarly, Saka et al. (2019) posit that the drift in anticipated performance and delays experienced in the construction sector have impacted on their ability to effectively and efficiently meet project objectives and achieve value for the clients and investors monies. The industry was adjudged a 'sleeping giant' to further emphasis the many performance issues that evolve from its 
activities. These problems include time and cost overruns, abandonment of projects, waste and claims and conflicts among the stakeholders (Kolo \& Ibrahim, 2010). The contractor who is one of the major stakeholders in construction contracts has been blamed for this abysmal performance situation. This is because the contractors are the constructors of the construction works and their performance has oftentimes been used to rate the success of construction products.

Poor performance in areas of communication and information exchange among the parties to construction projects has been blamed as one of the major contributors to this issue. According to Sekou (2012), ineffective data and information communication and exchange within and amongst the project stakeholders is one of the central contributors to the poor performance experienced in the construction sector. Similarly, Lofgren (2006) reported that a higher percentage of the problems associated with production within the construction industry are strongly related to information exchange and communication within the construction project's parties. One of the contributors to performance issues is lack of effective information management; thus, there is need for contractors to leverage on ICT tools to change the traditional approach and improve performance (Saka \& Chan, 2020). Furthermore, poor information system which results in non-availability or improper storage of data and information for easy retrieval and application on future construction projects (Aghimien et al., 2019), has contributed greatly to the continuous use of unsustainable approach to project delivery. Eze et al. (2019) also observed that funding issues, management support and commitment, the fragmentation of construction business, project participants' poor management of communication, unqualified and inexperienced staff were the major factors limiting innovations in construction.

A typical construction project involves a series of tasks and actions, coordinated in an orderly manner for the overall achievement of the project goals (Onyeagam et al., 2019). These construction processes demand daily, a lot of data and information exchange among the participants to the project (Maqsood et al., 2004). Thus, the construction industry is an information and data laden industry which requires serious coordination among the various inter-reliant units, organisations and individuals to attain the project's cost, time and quality objectives (Toole, 2003). For success to be achieved in the delivery of projects, organizational goals and strategies must be rooted in a digital technology-driven knowledge realm (Halim, 2010). Construction services are delivered with fewer efforts and stress and with greater accuracy where participants embrace ICT; which should be seen as a 'norm' and not an 'idea' (Aghimient et al., 2018). To stay relevant in the larger construction market, construction firms must properly align their functions with trends in innovative ICT. ICT has proven to be an essential tool for making the construction industry to measure up with the ever-growing clients and regulators demands, as well as the complexity of the industry's products (Betts, 1999). Productivity has been enhanced in the construction industry through the adoption of innovative ICT facilities and tools (Liston et al., 2000). Amusan et al. (2018) posit that ICT brought a lot of innovative breakthroughs that have helped to increase productivity in the construction industry.

Mutesi and Kyakula (2011) assessed the application of ICT in the Ugandan construction industry, with the aim of determining the level of ICT penetration, impact and constraints within companies in Kampala. It was found that among the widely used software are; Microsoft word and excel, AutoCAD, PowerPoint, Masterbill and Microsoft project. The benefits of using ICT are increased productivity, time savings, 
reduced risks and mistakes, and simplified complex tasks. Peansupap and Walker (2006) investigated Innovation diffusion at the implementation construction phase of a project, with emphasis on information communication technology. The study reported that ICT application planning requires the consideration of variables such as management and technical support, favorable working environment, and the characteristics of the individual users of ICT, for effective framework development.

Extant literature exists on ICT and innovation in construction, especially in some developed economies. These include studies carried out in Denmark (Samuelson, 2002), Canada (Rivard, 2000), Malaysia (Lim et al., 2002), South Africa (Arif \& Karam, 2001), Singapore (Goh, 2005), and in Turkey (Sarshar \& Isikdag, 2004). However, there is no known study by the researchers on the benefits of innovative ICT facilities deployment in construction projects, especially in the study area. With the understanding of the significant impact of the physical and socio-economic environments on the quality of services delivered by construction organizations through their professional employees (Kazaz \& Ulubeyli, 2009), there is, therefore, the need to assess the benefits of innovative ICT facilities utilisation by construction organizations in Port Harcourt. Therefore, this study, aimed at assessing the benefits of innovative ICT facilities deployment in construction projects, taking the perspective of construction professional employees in Port Harcourt. The study hypothesis is, $\mathrm{H}_{0}$ : there is no significant difference in the perception of the different professionals regarding the benefits of innovative ICT deployment in construction.

The outcome of this study will propel and catalyze a rapid and a more comprehensive consideration and exploitation of innovative information and communication facilities used in construction processes by construction organisations. In addition, decision-makers in the industry will be spurred into actions that will entrench the application of ICT facilities in all construction processes and practices.

\section{Review of Related Literature}

\section{ICT Development and Deployment in Construction}

There is an increasing trend in the way construction organizations are responding to ICT facilities application in construction transactions. According to Amusan et al. (2018), the deployment of ICT has positively improved the competence of construction development. In recent times according to Amusan and Ayo (2017), exchange of data like pictures, schedules, drawings, and other contractual documents is made easy through the interconnection of information technology and telefax machines. Edocument management, e-tendering, teleconferencing, e-commerce, enterprise resource planning (ERP), e-procurement, modelling and visualization, among others; are innovative advanced information communication technology applications that have found used in and have been successfully deployed by participants in the construction industry of many nations (Amusan et al., 2018).

Early twenties researchers have linked these changes to the level of competition and globalization, innovative strategies being adopted by big firms, clients demands and sophistication, changing industry advancement in information and communications technology. Critical among these changes is the shift in companies' traditional paperbased approach to the use of computer-based techniques in the running of day-to-day activities of the firms (Alabi \& Anifowose, 2018). Halim (2010) pointed out that, the 
advent of innovative technologies have enhanced the operations of construction organizations globally.

Similarly, Peansupap and Walker (2005) posit that evolving ICT have presented prospects for refining and making communication within construction processes to be more effective at every facet of the construction projects, and in creating a new market for businesses. It was further stressed that ICT related expenditure now forms a larger chunk of the overall construction firms annual running cost. Although, ICT deployment in the construction industry is still relatively low (Woksepp \& Olofsson, 2006). However, the awareness of ICT utilization is high, the high cost of deployment and upgrading of the system, have limited the usage, especially for smaller firms. The integration of different ICT facilities within the industry and among the construction professionals is important. ICT integration in construction has increased the quality of outputs, shortens work delivery time, enhanced financial control, and improves access to data and productivity (Onyegiri et al., 2011).

In the UK, construction firms see benefits in implementing and using new technologies, which will assist in the attainment of strong competitive advantage. This importance is, however, most times ignored due to their unwillingness to invest in new innovative technologies. Returns on investment have always hindered and prevented most decisions to invest in ICT. In Turkey, Sarshar and Isikdag (2004) opined that there are inefficient communication and loss of information due to fragmentation in the industry. Although, the deployment level of ICT in construction is still at the infancy.

The essential tools for ICT deployment are physical hardware and software. While the physical hardware comprises majorly of the different types of computerized gadgets, the software ranges from word processing software to design software. The common types of software used in construction include Word processing; Spreadsheet; CAD (Revit, AutoCAD, ArchiCAD); Internet software; BIM (Building Information Model); RFID (Radio Frequency Identification); MasterBill, Super Project, WinQs, QSlotus, Digitizers, Computer-Aided Taking Off (CATO), Estimator Pro.MB 3, QS Cad, RIPAC, EVEREST, Kwikest, Microsoft Navision; Project extranet; Microsoft project etc. Arif and Karam (2001) stated that this software find used in presentation and project management, contract administration, desktop publishing and marketing. While architects, engineers and contractors use CAD mostly for design, drawing and presentation, quantity surveyors use it for measurement, preparation of bills of quantities (BOQ), estimating, and presentation. Mesároš and Mandičák (2017) found that there is a significant relationship between ICT adoption and construction firms and projects performance. Also, ICT usage in almost all the activities of the construction industry has an indisputable significant effect on the performance of construction projects (Amusan et al., 2018). Furthermore, the laborious and time-consuming tasks in the existing traditional approach, have been changes and improvement recorded as a result of the usage of ICT applications (Ganesh \& Prakriti, 2016).

\section{Benefits of Innovative (ICT) Facilities Deployment in Construction}

It has been reported that the problems such as complexity, operational fragmentation, time constraints, has compelled a lot of enterprises of all sizes and dimensions, to integrate ICT into their business processes (Vadhavkar \& Pena-Mora, 2000; Hassan \& McCaffer, 2002). The implementation of ICT technologies in construction is aimed at supporting information sharing among individuals, groups and organizations. Hassanain et al. (2000) posit that the construction industry of today and future demand the use of 
information and communication technologies enable-system. According to Bowden (2005), ICT provides construction firms with new opportunities to enhance communication, information management processes and collaboration. Owner organizations are requiring the architecture, engineering, procurement and construction industry to perform at unusual levels of project delivery. The overall performance of the construction industry has improved tremendously through, the use of information technologies (Songer et al., 2000). Even though, the industry participants are slow and unyielding to fully embrace the adoption and use of new technologies to enhance project performance to desired levels. Appropriate deployment and implementation of information and communication technology in the construction industry offers effects like shortening of schedules, a better quality of work, reduced costs, increase the flexibility of construction organisation (Songer et al., 2001). It was reported that investment in ICT in construction is increasing yearly and constitutes a major part of the total project cost (Löfgren, 2007). The achievement of radical changes in construction business process is triggered and enabled by ICT (Isikdag et al., 2007).

Mutesi and Kyakula (2011) studied the application of ICT in the construction industry of Kampala, and found that the benefits drivable from ICT are reduced documentation mistakes, make complex tasks easy, savings in time and productivity improvement. Ugwu et al. (2006) compared ICT applications in Hong Kong and Australia and reported that the importance of ICT in construction business span across strategic, tactical and operational levels. In a similar but separate study, Ugwuanyi and Ugwu (2015) grouped the benefits of ICT into strategies, tactical and operational benefits. The chief benefits of ICT in construction were enhanced competitive advantage, improved client satisfaction, improved organizational and process flexibility, improved service quality, improvement of contract administration, improve teamwork, improved data management, improved communication, and data exchangeability improvement.

Ahuja et al. (2009) developed an Interpretive structural model (ISM), which shows four categories of benefits of ICT in building project management. These benefits which are projects, team management, technology, and organization cannot be achieved in isolation because they are inter-related. The organization and technology-associated benefits are known as the strategic benefits; thus have a powerful driving force for the project team organizations. It was further advocated that the application of ICT increases the strategic benefits of the organization. It is critical for construction professionals to have a firm understanding of the driving force and dependence link that exist between and among the benefits. This will help firms to develop a workable plan for adopting suitable ICT at the right time for developing the organization and project management. The need for service delivery efficiency enhancement and product branding, have been reported as factors that influenced the ICT deployment (Oyetunji et al., 2018). Alaghbandrad et al. (2011) maintain that ICT makes a crucial facet of technology that spans across any product that will store, retrieve, manipulate, transmit or receive information electronically.

\section{Research Methodology}

This study covered the assessment of the benefits of Innovative (ICT) Facilities deployment on construction projects delivery by construction organizations in Port Harcourt. The choice of selecting Port Harcourt is based on the evidence that Port Harcourt is located in rivers state, which is one of the oil-rich states of Nigeria. The 
presence of this natural endowment in the state, attract both local and foreign investors, professionals, developers, and even researchers to Port Harcourt. The government of the day is implementing many construction and developmental projects around the city of Port Harcourt. Thus, the in-flux of various construction firms, consultants, construction professionals to Port Harcourt.

A well-structured questionnaire was adopted for the study, and the researchers administered them personally to the target respondents. The questionnaire is one of the most used techniques for conducting social research, and it involves the formulation of precise written questions for the respondents, whose opinion is being sorted (Blaxter et al., 2001). The questionnaire used has two sections. Section A of the questionnaire was used to gather data on the respondents' background. The information collected in this section will serve a quality check to the data obtained from the other sections of the questionnaire. Section B assessed the benefits of the deployment of innovative ICT facilities in construction projects. Information derived from related literature reviewed, facilitated the design of the research instrument. The questionnaire was designed on a five-point Likert scale, with 5 being very high, 4 being high, 3 being average, 2 being low and 1 being very low.

Population is a collection of elements being studied and about which conclusions are to be drawn (Kothari, 2004). The populations for this study are professionals in construction-based organizations (i.e. civil and heavy engineering contractors, building contractors and housing developers) in the study area. These professionals include Civil and Services Engineers, Professional builders, Architects, Quantity Surveyors, Estate surveyors and vaulters. A total of 372 questionnaires were administered within the period of the study, using simple random sampling techniques. The respondents were given a considerable amount of time to reflect and enable them to give valid responses to the items contained in the research instrument. 260 questionnaires were retrieved, 6 were rejected on the ground that they were not completely and properly filled. Only 254 were deemed fit and were used for the analysis. This represents an effective response rate of 68.28 percent. This response rate is higher than 20 to 30 percent for questionnaire surveys suggested by Akintoye (2000), for construction management studies.

The collected data were analyzed using Percentages, Mean Item Score (MIS), and Kruskal-Wallis $\mathrm{H}$ test. Tables were used to present the analyzed data. The data collected on the benefit of ICT deployment was analyzed and ranked using Mean item score. The Hypothesis was tested using the Kruskal-Wallis H test. Kruskal Wallis H test was used for two purposes. (1) to determine if there exist statistically significant differences in the opinions of the respondents. (2) to ascertain the variables in which the respondents' view varies. As a rule, accept hypothesis when $\mathrm{P}$-value $\geq 0.05$, and fail to accept hypothesis when P-value $<0.05$. Also, the cut-off point for the determination of the level of importance, satisfaction or significance of the variables using mean item score or relative frequency (or percentage) index are (0-30 percent) - Very Low, (31-50 percent) - Low, (51-70 percent) - Average, (71-90 percent) - High, and (91-100 percent) - Very High. The decision rules for using Kruskal-Walis test at 95 percent significance level are;

i. $\quad$ accept hypothesis; if $\mathrm{P}$-value $\geq 0.05$; this implies a non-significant difference (convergent/existence of relationship)

ii. reject hypothesis; if $\mathrm{p}$-value $<0.05$; this implies a significant difference (divergent/non-existence of relationship) 
Microsoft excel for windows and Statistical package for social science (SPSS) Version 20 was used to organize the data and carry out the analyses.

Prior to the final draft of the questionnaire, a pilot survey was adopted to test the appropriateness and correctness of the questionnaire to solving the study problem. Fellows and Liu (2008) suggested a pilot study for suitability of the research instrument to meeting study aim. 12 of the initial draft questionnaire were randomly circulated to some selected experts and based on the feedback, the final draft was made.

Furthermore, to ascertain the accuracy of the results that would be obtained from the research instrument, a reliability test was done using Cronbach's alpha test $(\alpha)$ as suggested by (Kothari, 2004). This test was utilized to determine the dependability and internal consistency of the extracted data from the research instrument. Pallant (2005) posits that an alpha $(\alpha)$ value of 0.70 and above is ideal, and the closer alpha $(\alpha)$ is to 1 , the more the internal dependability and strength of items in the questionnaire. The Cronbach alpha value of 0.808 was obtained for the variables as detail in Table 1 . With this value, the questionnaire was adjudged credible, reliable and has high internal consistency.

\section{Table 1 Reliability Test}

\begin{tabular}{|c|c|c|c|c|c|}
\hline & \multicolumn{5}{|c|}{ Case Processing Summary } \\
\hline \multirow{3}{*}{ Cases } & Valid & 254 & 100 & Cronbach's Alpha & 0.808 \\
\hline & Excluded $^{\mathrm{a}}$ & 0 & 0 & $\mathrm{~N}$ of Items & 20 \\
\hline & Total & 254 & 100 & & \\
\hline
\end{tabular}

Source: Author

\section{Normality Test}

To ascertain the suitability of the Kruskal Wallis test for testing the hypothesis, a normality test was first used on the data collected. This was done to establish whether the data is parametric or non-parametric. It was suggested by Ghasemi \& Zahediasi (2012) that Shapiro-Wilk normality test be used for studies whose sample size is less than 2000. Thode (2002) confirmed that the Shapiro-Wilk test is the best choice for testing the normality of non-parametric data. The criterion for normality is when the sig. $<0.05$. The analysis on Table 2 revealed that all the variables have a significant value of 0.000 , this fell within the criteria for normality (i.e. p-value $<0.05$ ). This indicates that the data are non-parametric in nature, and they are, therefore, ideal for KruskalWalis test. Kruskal Walli $\mathrm{H}$ test is suitable for determining the existence of a significant difference in the perception of three or more groups of respondents. The target respondent group for this research is five (5).

Table 2 Result of Normality Test

\begin{tabular}{lccc}
\hline & \multicolumn{3}{c}{ Shapiro-Wilk } \\
\cline { 2 - 4 } Variables & Statistic & df & Sig. \\
\hline Improved communication & 0.903 & 254 & 0.000 \\
Reduced rework and waste & 0.829 & 254 & 0.000 \\
Reduces construction errors & 0.825 & 254 & 0.000 \\
Improved organizational and process flexibility & 0.848 & 254 & 0.000 \\
Reduces mistakes/errors in contract documents & 0.686 & 254 & 0.000
\end{tabular}




\begin{tabular}{llll} 
Improved customer/ supplier satisfaction & 0.873 & 254 & 0.000 \\
Time saving & 0.901 & 254 & 0.000 \\
Improved contract administration & 0.913 & 254 & 0.000 \\
Improved service quality & 0.896 & 254 & 0.000 \\
Improve teamwork & 0.875 & 254 & 0.000 \\
Reduces proportion of new work & 0.873 & 254 & 0.000 \\
Increased productivity of employees & 0.738 & 254 & 0.000 \\
Enhanced marketability and competitiveness & 0.754 & 254 & 0.000 \\
Reduced paperwork & 0.900 & 254 & 0.000 \\
Improvement in the ability to exchange data & 0.729 & 254 & 0.000 \\
Improvement in data management & 0.752 & 254 & 0.000 \\
Reduces degree of difficulty & 0.835 & 254 & 0.000 \\
Reduced time to compile tenders & 0.876 & 254 & 0.000 \\
Ease of doing complex tasks & 0.715 & 254 & 0.000 \\
improves document quality & 0.905 & 254 & 0.000 \\
\hline
\end{tabular}

Source: Author

\section{Analysis, Results and Discussion}

\section{General characteristics of the respondents}

The analysis of the data gathered on the general features of the respondents is shown in table 3 . In terms of year of experience, about 6.3 percent of the respondents have 5 years and below working experience, 28.74 percent of the respondents have 6 to 10 years working experience, 31.10 percent of the respondents have 11 to 15 years working experience, 18.90 percent of the respondents have 16 to 20 years working experience and lastly, 14.96 percent have 21 years and above working experience. The average working experience of the respondents was put at 11.5 years.

In a nutshell, it was inferred that these respondents have spent a good length of time in their present organizations and have the requisite experiences to give a reasonable and reliable insight to the happenings within their organizations. Furthermore, majority of the respondents are Engineers with 36.22 percent, followed by the Quantity surveyors with 30.71 percent, then the Architects with 12.6 percent, then Builders with 10.63 percent, and lastly, the Estate valuers with 9.84 percent. The highest academic qualification of the respondents is Masters of Science/Technology (44.88 percent), followed by those with Bachelor of Science/Technology (30.31 percent), then Higher National Diploma (22.44 percent) and finally, those with Doctorate holders (2.36 percent). This result suggested that the respondents are academically equipped to make an informed contribution to the subject under consideration. Surprisingly, 82.28 percent of the respondents indicated that their firms engage the services of ICT specialist and 17.72 percent of them indicated that their firms do not engage the services of ICT specialist. This implies that only 17.72 percent rely on the services of external/contract ICT specialist based on needs. Since a larger number of firms engage the services of an in-house ICT specialist; it means Innovative ICT technologies have been embraced by construction firms in the area of the study.

The findings from the background information of the respondents indicate that responses gathered from them can be relied upon in making a valid and generalized conclusion on the subject under consideration. 
Table 3 Demographic characteristics of Respondents

\begin{tabular}{llccc}
\hline Category & Classification & Freq. & \% & Cum. \% \\
\hline Years of work experience & 1 to 5years & 16 & 6.3 & 6.3 \\
& 6 to 10 years & 73 & 28.74 & 35.04 \\
& 11 to 15 years & 79 & 31.1 & 66.14 \\
& 16 to 20 years & 48 & 18.9 & 85.04 \\
& 21 and above & 38 & 14.96 & 100 \\
Professions of Respondents & TOTAL & $\mathbf{2 5 4}$ & $\mathbf{1 0 0}$ & \\
& Architects & 32 & 12.6 & 12.6 \\
& Builders & 27 & 10.63 & 23.23 \\
& Engineers & 92 & 36.22 & 59.45 \\
& Estate Surveyors \& valuers & 25 & 9.84 & 69.29 \\
Academic Qualification & Quantity Surveyors & 78 & 30.71 & 100 \\
& TOTAL & $\mathbf{2 5 4}$ & $\mathbf{1 0 0}$ & \\
& Higher national diploma & 57 & 22.44 & 22.44 \\
& BSc./B.Tech & 77 & 30.31 & 52.76 \\
& MSc./M.Tech & 114 & 44.88 & 97.64 \\
Firms Engagement of ICT & PhD holders & 6 & 2.36 & 100 \\
expert/specialist & TOTAL & $\mathbf{2 5 4}$ & $\mathbf{1 0 0}$ & \\
& Yes & 209 & 82.28 & 82.28 \\
& No & 45 & 17.72 & 100 \\
\hline
\end{tabular}

Source: Author

\section{Benefits of Innovative (ICT) Facilities Deployment in Construction}

Table 4 displays the result of the analysis of the data collected on the benefits of innovative ICT deployment in construction. The result shows that the top five (5) most important benefits of ICT deployment are Increased productivity of employees (MIS $=4.51$ ), Reduces mistakes/errors in contract documents (MIS = 4.47), Time saving (MIS=4.47), Enhanced marketability and competitiveness (MIS = 4.46), and Ease of doing complex tasks (MIS=4.44). Other highly ranked benefits which lie between $6^{\text {th }}$ to $10^{\text {th }}$ positions are improved ability to exchange data, improved data management, Reduces construction errors, improved organizational and process flexibility, and improved communication. This result is in line with the findings of Ugwu et al. (2006), Mutesi and Kyakula (2011), and Ugwuanyi and Ugwu (2015). Mutesi and Kyakula (2011) reported that the top benefits obtainable from the implementation of ICT is the reduction of mistakes and errors in contract documents, easing complex tasks, increases productivity and save time. The finding also supports the assertion of Songer et al. (2001). It was observed that the deployment of ICT in the construction industry helps to shorten schedules, improve quality of work, and reduce cost. Ugwu et al. (2006) further stated that the strategic benefits of ICT application in construction are improved organisational and process flexibility, improved customer/supplier satisfaction, improved customer/supplier relations, enhanced competitive advantage, and improved growth and success. The tactical benefits include improved service quality, improved response to changes, and improved teamwork. Operational benefits are improved ability to exchange data, improved quality of output, improved communication and improved data management. Ugwuanyi and Ugwu (2015) reported that one of the strategic benefits of ICT implementation is to enhance competitive advantage. It was found that main benefits of ICT in construction are improved client satisfaction, improved organizational and process flexibility, improved service quality, improved contract administration, Improve teamwork, improved data management, improved communication, and 
improved ability to exchange data. These cut across strategic, tactical and operational benefits drivable from the implementation of ICT in construction.

On average, the mean item score for the benefits is 4.22 ( 84.40 percent). This implies that all the benefits are obtained from the adoption of innovative ICT facilities in construction. Thus, very high benefits are derived from the adoption and implementation of innovative information and communication technology facilities in construction.

Furthermore, Kruskal Walli test was carried out to ascertain the variables in which the view of the respondents varies significantly. From table 4, it can be seen that there was an agreement in the views of the respondents on 16 ( 80 percent) benefits of ICT deployment. The 16 variables have their p-value to be greater than 0.05 . There were, however, disagreements of opinions on 4 (20 percent) benefits. These include reduced rework and waste, Reduces construction errors, and time saving. The p-value of these variables is less than 0.05 meaning that there is a significant statistical difference in the view of the respondents regarding these benefits of ICT adoption in construction. This observed difference may be attributed to the different level of application and individual views of the different organizations sampled. With 80 percent agreement, it could be inferred that there is no significant difference in the view of the different professional concerning the benefits of innovative ICT deployment in construction. This implies that the benefits of implementation and adoption of innovative ICT in construction will yield the same impact regardless of construction organizational type and category.

Table 4 Benefits of ICT deployment in Construction Project

\begin{tabular}{lcccccc}
\hline \multirow{2}{*}{ Variables } & \multirow{2}{*}{ MIS } & \multirow{2}{*}{ SD } & \multirow{2}{*}{ Rank } & \multicolumn{3}{c}{ Kruskal Wallis Test } \\
\cline { 5 - 7 } & & & & $\mathbf{X}^{\mathbf{2}}$ & P-value & Decision \\
\hline Improved communication & 4.27 & 0.899 & 10 th & 6.268 & 0.180 & Accept \\
Reduced rework and waste & 3.60 & 1.510 & 20 th & 11.66 & $0.020^{* *}$ & Reject \\
Reduces construction errors & 4.38 & 1.013 & 8 th & 10.75 & $0.030^{* *}$ & Reject \\
Improved organizational and process & 4.35 & 0.957 & 9 th & 1.832 & 0.767 & Accept \\
flexibility & & & & & & \\
Reduces mistakes/errors in contract & 4.47 & 0.869 & 2 nd & 2.150 & 0.708 & Accept \\
documents & 4.17 & 1.084 & 14 th & 7.208 & 0.125 & Accept \\
Improved customer/ supplier satisfaction & 4.47 & 0.869 & 2 nd & 12.62 & $0.013 * *$ & Reject \\
Time saving & 4.11 & 1.094 & 15 th & 7.093 & 0.131 & Accept \\
Improved contract administration & 4.27 & 0.899 & 10 th & 6.806 & 0.146 & Accept \\
Improved service quality & 4.11 & 1.130 & 15 th & 5.027 & 0.285 & Accept \\
Improve teamwork & 3.80 & 1.228 & 19 th & 3.281 & 0.512 & Accept \\
Reduces proportion of new work & 4.51 & 0.809 & 1 st & 4.030 & 0.402 & Accept \\
Increased productivity of employees & 4.46 & 0.874 & 4 th & 5.672 & 0.225 & Accept \\
Enhanced marketability and competitiveness & 3.81 & 1.188 & 18 th & 0.129 & 0.998 & Accept \\
Reduced paperwork & 4.43 & 0.966 & 6 th & 1.337 & 0.855 & Accept \\
Improvement in the ability to exchange data & 4.43 & 0.966 & 6 th & 2.591 & 0.628 & Accept \\
Improvement in data management & 4.07 & 1.231 & 17 th & 10.05 & $0.040^{* *}$ & Reject \\
Reduces degree of difficulty & 4.22 & 1.134 & 13 th & 1.505 & 0.826 & Accept \\
Reduced time to compile tenders & 4.44 & 1.150 & 5 th & 6.276 & 0.179 & Accept \\
Ease of doing complex tasks & 4.22 & 1.334 & 12 th & 2.983 & 0.561 & Accept \\
improves document quality & & & $4.22(84.40 \%)$ & &
\end{tabular}
**Sig. $<0.05$

4.22(84.40\%)

Source: Author 
To confirm that the benefits of implementation and adoption of innovative ICT in construction will yield the same impact regardless of construction organizational type and category, a further test shown in Table 5 was carried out. The result reinforced the conclusion that there is no significant difference in the perception of the different professionals regarding the benefits of innovative ICT deployment in construction. The premise for this is evident in the p-value which is greater than 0.05 across the respondent group. With this, the hypothesis $\left(\mathrm{H}_{0}\right)$ is accepted.

Table 5 Kruskal-Walis test for the Benefits of Innovative ICT Deployment

\begin{tabular}{lccccc}
\hline & Target Group & $\begin{array}{l}\text { Mean } \\
\text { Rank }\end{array}$ & $\begin{array}{l}\text { Chi } \\
\text { Sq. }\end{array}$ & P-value & Decision \\
\hline & Arch. & 104.27 & & & \\
Benefits of Innovative ICT & Bldr. & 124.81 & & & Accept \\
Deployment & Engr. & 138.76 & 6.412 & 0.170 & \\
& Estv. & 113.20 & & & \\
\hline
\end{tabular}

$\mathrm{N}=32$ for Architects(Arch.), $\mathrm{N}=27$ for professional Builders(Bldr.), $\mathrm{N}=51$ for EngineersCivil/Services (Engr.), N=25 for Estate Surveyors \& valuers(Estv.), N = 78 for Quantity Surveyor (Q.S) df $=4$

Source: Author

Relationship between the year of experience (YoE) and academic qualification (AQ) and ranking of variables by respondents

To find out if the year of experience (YoE) and academic qualification (AQ) of the respondents have a moderating effect on the ranking of the respondents, Kruskal Wallis Test was carried out. In all the analyses as shown in table 6 , the results indicate that the $\mathrm{P}$-values are less than 0.50 which is the significant level set for the study. This implies a significant statistical difference between the working experience and academic qualification and the respondents ranking. The decision, therefore, is to reject that working experience and academic qualification has no significant moderating effect on the ranking of the respondents. The ranking of the variables recorded in the study could have been influenced by other latent and extraneous factors beyond the scope of this study. Also, individual knowledge of the importance of information, communication and technology in the global economy and construction particularly could have been taken precedence. Finally, organizational culture, policies and strategies regarding innovation and competition in the construction industry could have also influenced the rating of the respondents

Table 6 Effect of working experience and academic qualification on the respondents ranking of variables

\begin{tabular}{lccccc}
\hline & Target Group & Mean Rank & Chi Sq. & P-value & Decision \\
\hline & Arch. & 30.75 & & & \\
Bldr. & 53.00 & & & Reject \\
Year of experience & Engr. & 104.22 & 215.269 & 0.0000 & \\
& Estv. & 149.32 & & & Reject \\
& Q.S. & 213.45 & & & \\
Arch. & 29.00 & & & \\
Quadification & Bldr. & 33.96 & & & \\
& Engr. & 113.65 & 220.084 & & \\
& Estv. & 191.5 & & & \\
\hline
\end{tabular}




\begin{tabular}{lccccc} 
& Arch. & 25.88 & & & \\
Year of & Bldr. & 36.83 & & \\
experience/Academic & Engr. & 110.20 & 224.7435 & 0.0000 & Reject \\
Qualification & Estv. & 178.06 & & & \\
& Q.S. & 204.79 & & & \\
\hline
\end{tabular}

Source: Author

\section{Conclusion and Recommendations}

This study set out to assess the benefits of innovative ICT facilities deployment in construction projects. Utilizing a survey approach to gather quantitative data from construction professional employees in Port Harcourt, the study was able to ascertain the most important benefits of adoption of innovative ICT facilities in construction. From the findings, it was concluded that there is no significant difference in the perception of construction professionals regarding the benefits of innovative ICT deployment in construction. Regardless of the organizational type and category within the construction industry, the benefit of ICT is the same. The most important benefits of ICT deployment in construction are increased productivity of employees, reduces mistakes/errors in contract documents, time saving, enhanced marketability and competitiveness and ease of doing complex tasks. These benefits cover organizational strategic, tactical and operation needs, especially in meeting customer satisfaction and remaining on top of competitors in the construction market.

Regardless of the limiting variables within and outside an organization, it is recommended that adequate planning and budget should be put in place to adopt innovative technologies to improve employees' performance and productivity. This will extend to adopting careful and neat ways of doing work with minimal or no errors, and the task will be done at better and greater speed. The output of documents from the ICT inclined organizations will have better quality and add to the marketability of the firms. A similar study could be carried out to establish more benefits of ICT in construction businesses. Also, the role of ICT in suppliers and manufacturers of building construction materials could be assessed. 


\section{References}

Aghimien, D., Aigbavboa, C., Oke, A., \& Koloko, N. (2018). Digitalisation In Construction Industry: Construction Professionals Perspective. In: Shiau, J., Vimonsatit, V., Yazdani, S., and Singh, A. (Ed). Conference paper on Streamlining Information Transfer between Construction and Structural Engineering. CON-141-147.

Aghimien, D.O., Aigbavboa, C.O., \& Thwala, W.D. (2019). Microscoping the challenges of sustainable construction in developing countries. Journal of Engineering, Design and Technology, 17(6), 1110-1128

Ahuja, V., Yang, J., \& Shankar, R. (2009). Benefits of collaborative ICT adoption for building project management. Construction Innovation, 9(3), 323-340.

Akintoye, A. (2000). Analysis of Factors Influencing Project Cost Estimating Practice. Construction Management and Economics, 18, p. 77-89

Alabi, T.T., \& Anifowose, O.M. (2018). Impact of Information and Communication Technology (Ict) Facilities Deployment on Quantity Surveying Practice in Abuja. In: Junaid, A. M., Adedayo, O.F, Jimoh, R.A. and Oyewobi, L.O. (Eds) Proceedings of the School of Environmental Technology International Conference (SETIC) 2018. 10th - 12th April 2018, School of Environmental Technology, Federal University of Technology, Minna, Niger State, Nigeria.

Alaghbandrad, A., Nobakht, M.B., Hosseinalipour, M., \& Asnaashari, E. (2011). ICT adoption in the Iranian construction industry: barriers and opportunities. Proceedings of the $28^{\text {th }}$ ISARC, Seoul, Korea, $280-285$.

Amusan, L.M., \& Ayo, C. (2017). Multi-Parameter Optimization of Cost Entropy For Reinforced Concrete Office Building Projects Using Ant Colony Optimization. Journal of Engineering and Applied Sciences, 12(9), 2260 - 2275.

Amusan, L.M., Oloniju, L.I., Akomolafe, M., Makinde, A., Nkolika-Peter, P., Farayola, H., \& Faith, O. (2018). Adopting Information and Communication Technology in Construction Industry. International Journal of Mechanical Engineering and Technology, 9(1), 739-746.

Arif, A.A., \& Karam, A. (2001) Architectural practices and their use of IT in the Western Cape Province, South Africa. Journal of Information Technology in Construction, 6, 17-34.

Betts, M. (1999). Strategic management of IT in construction, Blackwell, Oxford, UK.

Blaxter, L., Huges, C., \& Tight, M. (2001). How to research, 2nd Edition, Open University Press, London, UK.

Bowden, S. (2005). Application of mobile IT in construction. Dissertation, University of Loughborough, Department of Civil \& Building Engineering.

Eze, E.C., Sofolahan, O., Adegboyega, A.A., \& Saidu, K.J. (2019). Factors limiting the full-scale adoption of process and product innovation in the Nigerian construction industry. SEISENSE Journal of Management, 2(3). 67-81.

Fellows, R.R. \& Liu, A. (2008). Research Methods for Construction, 3rd Edition. Wiley- Blackwell Science, London.

Ganesh, P. \& Prakriti K.C. (2016). Role of ICT in construction.

Ghasemi, A. \& Zahediasl, S. (2012). Normality Test for Statistical Analysis: A guide for non- statisticians. International Journal of EndocrinolMetab, 10(2), 486489. 
Goh, B.H. (2005). IT barometer 2003: survey of the Singapore construction industry and a comparison of results. Journal of Information Technology in Construction, 10, $1-13$.

Halim, H.C. (2010). Assessment of The Application of Information and Communication Technology in Real Estate Practice. A Case Study of Lagos Metropolis. MSc. Thesis, University of Nigeria, Enugu.

Hassan T.M. \& McCaffer R. (2002). Vision of the large-scale engineering construction industry in Europe. Automation in Construction, 11(4), 421-437

Hassanain, M.A., Froese, T.M. \& Vanier, D.J. (2000). IFC-Based Data Model for Integrated Maintenance Management. Computing in Civil \& Building Engineering, Proceedings of the Eighth International Conference. ASCE, Virginia.

Isikdag U., Underwood, J., Kuruoglu, M., \& Acikalin, U. (2007). The Strategic Role of ICT within the TurkishAEC Industry. In: Haigh, R., \& Amaratunga, D. (Eds). Proceedings of CIB W89: Internetional Conference on Building Education and Research-Building Resilience, Kandalama, Sri Lanka.

Kazaz, A. \& Ulubeyli, S. (2009). Strategic management practices in Turkish construction firms. Journal of Management in Engineering, 25(4), 185-194

Kolo, B. \& Ibrahim, A. (2010). Value management: how adoptable is it in the Nigerian construction industry?. Paper presented at the West Africa Built Environment Research (WABER) Conference, Accra.

Kothari, C.R. (2004). Research Methodology; Methods and Techniques. 2nd Edition. New Delhi: New Age International.

Lim,Y.M., Rashid, A.Z., Ang, C.N.; Wong C.Y., \& Wong, S.L. (2002). A survey of Internet usage in the Malaysian construction industry. Journal of Information Technology in Construction, 7, 259-269.

Liston K.M., Fischer M.A., \& Kunz J.C. (2000). Designing and evaluating visualization techniques for construction planning. Proceedings of the 8th International Conference on Computing in Civil and Building Engineering (ICCCBE-VIII), Stanford University, Stanford, CA, 1293-300.

Löfgren, A. (2006). Mobile computing and Project communication - mixing oil and water?, Licentiate thesis, Royal Institute of Technology, Stockholm.

Löfgren, A. (2007). ICT Investment Evaluation and Mobile Computing Business Support for Construction Site Operations. Royal Institute of Technology, Sweden.

Maqsood, T., Walker, D.H.T., \& Finegan, A. D. (2004). An Investigation of ICT Diffusion in an Australian Construction Contractor Company Using SSM. Proc. of the joint CIB-W107 and CIB-TG23 Symposium on Globalisation and Construction, Bangkok, Thailand, 17-19 November, 485-495.

Mesároš, P., \& Mandičák, T. (2017). Impact of ICT on Performance of Construction Companies in Slovakia. IOP Conference Series: Materials Science and Engineering, 245, 1-9.

Mutesi, E.T. \& Kyakula, M. (2011). Application of ICT in the Construction Industry in Kampala. Second International Conference on Advances in Engineering and Technology, 263-269

Onyeagam, O.P., Eze, E.C., \& Adegboyega, A. A. (2019). Assessment of Quantity Surveying Firms' Process and Product Innovation drive in Nigeria. SEISENSE Journal of Management, 2(3), 21-37 
Onyegiri, K., Nwachukwu, C.C., \& Jamike, O. (2011). Information and communication technology in the construction Industry. American Journal of Scientific And Industrial Research, 2(3), 461-468

Oyetunji, A.K., Ojo, B., \& Oyetunji-Olakunmi, B. (2018). Factors Influencing the Deployment of ICT in Nigerian Real Estate Practice. Journal of African Real Estate Research, 3(1), 1-20.

Pallant, J. (2005). SPSS Survival Manual: A Step-By-Step Guide to Data Analysis Using SPSS for Windows (Version 12). 2nd Edition, Allen \& Unwin, Crows Nest NSW 2065 Australia

Peansupap, V. \& Walker, D.H.T. (2005). Factors enabling information and communication technology diffusion and actual implementation in construction organisations, ITcon, 10, 193-218.

Peansupap, V. \& Walker, D.H.T. (2006). Innovation diffusion at the implementation stage of a construction project: a case study of information communication technology. Construction Management and Economics, 24(3), 321-332

Rivard, H. (2000). A survey on the impact of information technology in the Canadian architecture, engineering and construction industry. Journal of Information Technology in Construction, 5, 37-56.

Saka, A.B. \& Chan, D.W.M. (2020). Profound barriers to building information modelling (BIM) adoption in construction small and medium-sized enterprises (SMEs): An interpretive structural modelling approach. Construction Innovation, 20(2), 261-284.

Saka, A.B., Olaore, F., \& Olawumi, T.O. (2019). Post-contract material management and waste minimization: an analysis of the roles of quantity surveyors", Journal of Engineering, Design and Technology, 17(4), 793-807.

Samuelson, O. (2002). IT-Barometer 2000 - the use of IT in the Nordic construction industry. Journal of Information Technology in Construction, 7, 1-26.

Sarchar, M. \& Isikdag, U. (2004). A survey of ICT use in the Turkish construction industry. Engineering, Construction and Architectural Management (ECAM), 11(4), 238-247.

Sekou, E. A. (2012). Promoting The Use of ICT In The Construction Industry: Assessing The Factors Hindering Usage By Building Contractors In Ghana. Msc Thesis, Kwame Nkrumah University of Science and Technology-Kumasi, Ghana.

Songer A.D., Young R., \& Davis K. (2001). Social Architecture for Sustainable IT Implementation in AEC. Digital Library of Construction Informatics and Information Technology in Civil Engineering and Construction.1-17. DOI : http://itc.scix.net/cgi-bin/works/Show?w78-2001-26.

Songer, A.D., Diekmann, J., Hendrickson, W., \& Flushing, D. (2000). Situational Reengineering: Case Study Analysis. Journal of Construction Engineering and Management, 126 (3), 185-190

Thode, H.J. (2002). Testing for normality. New York: Marcel Dekker.

Toole, T.M. (2003). Information technology innovation: a view of large contractors. Proceedings of the ASCE Construction Research Congress, Honolulu, Hawaii. Retrieved from http://www.facstaff.bucknell.edu/ttoole/ITinnovation.doc

Ugwu, O.O, Kumaraswamy, M.M., Ng, T., \& Love, P. (2006). ICT applications in construction: a comparative study of benchmarks, benefits, costs \& risks between Hong Kong and Australian construction firms. Joint International 
Conference on Computing and Decision making in Civil and Building Engineering, Montreal, Canada, June 14-16, 830-839.

Ugwuanyi, D.C. \& Ugwu, O.O. (2015).The Impact of Information and Communication Technology (ICT) Application in Nigerian Construction Industry. NJISS, 12(1), $1-16$.

Vadhavkar, S. \& Pena-Mora, F. (2000). Geographically Distributed Team Interaction Space. Computing in Civil \& Building Engineering, Proceedings of the Eighth International Conference, ASCE, Virginia.

Woksepp, S. \& Olofsson, T. (2006). Using Virtual Reality on a Large-Scale Industry Project. ITCon Electronic Journal of Information Technology in Construction, 11, 627-640 